\title{
Kronik boyun ağrılı hastada muayene yöntemleri
}

\author{
Examination methods in patients with chronic neck pain
}

\author{
Hakan Gündüz, Selin Balta
}

Marmara Üniversitesi Tıp Fakültesi, Fiziksel Tıp ve Rehabilitasyon Anabilim Dalı, Algoloji Bilim Dalı, İstanbul

\begin{abstract}
Boyun ağrısı, en sık karşılaşılan kas iskelet sorunlarından biri olup bel ağrısından sonra ikinci sıklıkta görülmektedir. Yıllık prevalansı \%30 kadardır. Akut olarak başlayan boyun ağrılarının \%30'u kronikleşerek, tedavi maliyetlerini arttırmakta ve iş gücü kaybına yol açmaktadır. Servikal omurga, kompleks yapısı ve oldukça hareketli olması nedeniyle dejeneratif süreçlere ve travmaya yatkındır. Kronik boyun ağrılarında başlıca nedenler; miyofasyal ağrı ve kötü postür kaynaklı mekanik ağrı, aksiyel boyun ağrısı, servikal radikülopati ve spondilotik miyelopatidir. Muayene; inspeksiyonla başlayıp, palpasyon, eklem hareket açıklığı muayenesi, özel servikal testlerin uygulanması ve ayrıntılı nörolojik muayeneyi içermelidir. Ayrıntılı ve dikkatli bir fizik muayene, en uygun tetkikleri ve tedavi yöntemlerini seçmeyi kolaylaştıracaktır. Bu nedenle de, fizik muayene, genel sağlığın iyileştirilmesinde, zaman ve iş gücü kaybının da önüne geçilmesinde kilit rol oynamaktadır.
\end{abstract}

Anahtar sözcükler: boyun; servikal; muayene; boyun muayenesi; kronik boyun ağrısı
Neck pain is one of the most common musculoskeletal problems and is second most commonly seen after low back pain. Its annual prevalence is around $30 \%$. Thirty percent of neck aches that start acutely become chronic, increasing treatment costs and leading to loss of work power. The cervical vertebrae are prone to degenerative processes and trauma due to the complex structure and high mobility. The main causes of chronic neck pain are myofascial pain and poor posture-derived mechanical pain, axial neck pain, cervical radiculopathy and spondylotic myelopathy. Assessment should start with physical examination and include palpation, measurement of range of motion of joints, performing of special cervical tests and a detailed neurological examination. A detailed and careful physical examination will facilitate optimal choice of examination materials and treatment methods. Therefore, physical examination plays a key role in improving general health and avoiding loss of time and work power.

Key words: neck; cervical; examination; neck examination; chronic neck pain

\section{$\mathrm{B}$} oyun ağrısı, en sık karşılaşılan kas-iskelet sorunlarından biri olup bel ağrısından sonra ikinci sıklıkta görülmektedir. Kadın cinsiyette biraz daha sık görülüp prevalansı \%27,2 iken, erkeklerde $\% 17,4^{\prime}$ tür. ${ }^{[1,2]}$ Akut olarak başlayan boyun ağrılarının \%30'u kronikleşerek tedavi maliyetlerini arttırmakta ve iş gücü kaybına yol açmaktadır. ${ }^{[3-5]}$ Boyun bölgesinde ağrı hisseden hastaların ağrılarının, \%28,8'inin çok şiddetli, \%10,4'ünün her gün ve günde birçok kez, $\% 3,6$ 'sının ise çok engelleyici özellikte olduğu gösterilmiştir. ${ }^{[6]}$

Kronik boyun ağrılarında başlıca nedenler; miyofasyal ağrı ve kötü postür ile ilişkili mekanik ağrı, aksiyel boyun ağrısı, servikal radikülopati ve spondilotik miyelopatidir.
Aksiyel boyun ağrısı, boyundaki yapılardan kaynaklanan, spinal sinir kökünün etkilenmesine bağlı, kola ve önkola yayılan bölgesel ağrıdır. İntervertebral disk ve faset eklemlerinden kaynaklanan ağrılar omuz ve sırta yayılabilir. Faset eklem ağrısı, aksiyel boyun ağrısının önde gelen nedenidir. Ağrı, boynun arkasına, skapula mediyaline yayılabilir; ekstansiyon ve rotasyon hareketleri ile ağrıda artış gözlenir. Üst servikal eklemlerde ileri derecede dejeneratif artriti olan hastalar, boyun ya da kulağın arka tarafına yayılan suboksipital ağrı ile de başvurabilirler. ${ }^{[7]}$

Servikal radikülopatinin görülme sıklığı yaşla birlikte artmakta olup en sık 50'li yaşlarda görülür. Tabloya hakim olan süreç daha çok intervertebral disk dejenerasyonu ile ilgilidir. Bununla beraber, vertebra

- İletişim adresi: Prof. Dr. Hakan Gündüz, Marmara Üniversitesi Pendik Eğitim ve Araştırma Hastanesi, Fevzi Çakmak Mahallesi, Muhsin Yazıcıoğlu Cad. No: 10, Zemin kat, Oda No: 1628, Pendik, İstanbul Tel: 0216 -65706 06/1628 e-posta: drhakang@gmail.com

- Geliş tarihi: 20 Șubat $2017 \quad$ Kabul tarihi: 20 Şubat 2017 
korpusu, unkovertebral ya da faset eklemden kaynaklanan bir osteofitin yaptığı bası da radiküler ağrıya neden olabilir. Öksürme ve ıkınma gibi beyin omurilik sıvısı basıncını arttıran manevralar ağrıyı şiddetlendirir. Servikal radikülopatide, etkilenen seviyeye göre duyu bozukluğu, kas güçsüzlüğü ve kas germe reflekslerinde azalma veya kaybolma gözlenebilir. Duyu semptomları daha çok dermatomal, ağrı ise daha çok miyotomal yayılım gösterir. ${ }^{[8]}$

Servikal spondilotik miyelopati ise yaşlılarda spinal disfonksiyon ve nontravmatik spastik kuadriparezinin en sık nedenidir. Spinal kanalın ön-arka çapı, dinamik kord kompresyonu, medulla spinalisin vasküler desteğinin bozulması, servikal miyelopati tablosundaki önemli faktörlerdir. ${ }^{[9]}$ Orta yaş grubu bireylerin $\% 50$ 'sinden fazlasında radyolojik olarak spondilotik değişiklikler gözlense de, sadece \%10'unda spinal kord basısı ve servikal radikülopati semptomları görülmektedir. ${ }^{[10]}$

Servikal omurga, yedi vertebra, beş intervertebral diskten oluşmaktadır. C1 (atlas) ve C2 (aksis) segmentleri, anatomik olarak özellikli olup ayrı isimlendirilir. C2 ile C7 arasındaki vertebralar, önde intervertebral disk ve unkovertebral eklemle, arkada zigoapofizyal (faset) eklemle birleşmektedir. Bu segmentin yapısı, üstte oksiputun konveks kondilleri ile altta aksisin massa lateralisleri arasında yerleşmiş atlastan oluşur. Aksisin önemli bir yapısı olan odontoid çıkıntı (dens) atlas ve oksiputla doğrudan bağladıkları bir destek yapı oluşturur. Oksiput ile daha ağırlıklı olarak alar bağ ve apikal, krusiform bağın üst bölümü ile bağlantılıdır. Atlas ise odontoide krusiform bağın transvers bölümü ile C1-2 eklem kapsülü ve diğer C1-2 aksesuvar bağları ile bağlıdır. Servikal omurganın bağları ileri derecede esneklik gösterir. Bu esneklik sayesinde bağlar spinal kord ve sinirleri, boyunda oluşan stres ve travmaya karşı koruyabilmektedir. Vertebraların önünde bulunun anterior longitudinal bağ, intervertebral disklerin ve vertebra korpuslarının önünde yer alarak destekler ve ekstansiyonu limitler. Posterior longitudinal bağ ise intervertebral diskleri ve vertebra korpuslarını arkadan destekler. Ekstansiyonla gevşerken fleksiyonla gerilir. Supraspinöz bağ, interspinöz bağ ve ligamentum flavum fleksiyonda stabiliteyi sağlar. ${ }^{[11]}$

Boyun ağrılı hastanın muayenesi de diğer kas iskelet sistemi sorunlarının muayenesinde olduğu gibi inspeksiyonla başlar; palpasyon, eklem hareket açıklığı muayenesi ve özel servikal testlerin değerlendirilmesi ve ayrıntılı nörolojik muayeneyi içerir.

\section{INSPEKSIYON}

İnspeksiyon, hastanın muayene odasına girdiği anda başlamalı, hasta yürürken ve öykü alınırken mevcut olan özellikler not edilmelidir. Hastanın normal postürü, başının duruşu gözlenmeli, boyun bölgesi, kitleye bağlı şişlik, musküler asimetri, skar dokusu, renk değişikliği ve cilt lezyonları varlığı açısından incelenmelidir. ${ }^{[12]}$

\section{Postür Değerlendirmesi}

Klinisyen, hastanın oturur ve ayakta durur pozisyondaki postürünü değerlendirmelidir. Postürün değerlendirmesi bir bütün olarak ele alınmalıdır. Ön-arka değerlendirme alt ekstremite eşitsizliğini, pelvik asimetriyi ve skolyozu belirlemede; lateralden yapılan değerlendirme ise anatomik eğrilikleri, başı, omuzu ve pelvisi değerlendirmede yardımcıdır. Oblik bakıda ise spinal kontürler değerlendirilebilir. Doku irritasyonuna veya instabiliteye bağlı gelişebilecek anormal tonus, oblik izlemde fark edilebilir.

İdeal postürden olan sapmaları belirlemek için Kendall'in referans çizgileri ile karşılaştırmak gereklidir. ${ }^{[13]}$ Ağırlık merkezinin düşey çizgisi, kulağın eksternal meatusu, C1'in odontoid çıkıntısı, T1 ve T12 cismi, sakral promontorium, kalça eklemi merkezinin biraz arkası ve diz eklemi merkezinin önü, kalkaneoküboidal eklemin içinden, lateral malleolun hafif önünden geçer. Bu çizginin normalden sapması, spinal eğrilikleri etkiler. Boyuna yandan bakıldığında görülen eğrilik (lordoz), C1'den C7'ye uzanır. C1'in üzerindeki keskin açı, başın horizontal planda olmasına izin verir.

Mastoid seviyelerini değerlendirirken, klinisyen, avuç içleri yere bakmak suretiyle mastoid çıkıntıları işaret parmakları ile palpe eder. Asimetri bulunması, kraniyovertebral instabilite varlığını işaret edebilir.

Omuz kuşağı ve skapula seviyesinde ise klinisyen, başparmaklarını skapula alt uçlarına, diğer parmaklarını ise omuz üzerlerine yerleştirir. Asimetri saptanmaSı, torakal omurgada skolyoz veya omuz kuşağı kaslarındaki dengesizlik (üst trapezius ve levator skapulada kısalık, alt trapezius ve serratus anteriorda güçsüzlük) ile ilişkilendirilebilir.

Janda ve arkadaşları tarafindan, 1994 yılında, "shoulder-crossed" sendromu olarak ifade edilen ve üst servikal sorunlarla sonuçlanan bir postür bozukluğu tanımlanmıştır. ${ }^{[14]}$ Bununla beraber, 1994 yılında Watson ve arkadaşları, baş önde postür bozukluğunu tanımlamıştır. ${ }^{[15]}$ Bu postür bozuklukluklarında, üst trapezius, levator skapula, sternokleidomastoid, skalenius, suboksipitalis, pektoralis major/minor ve subskapularis kaslarında kısalık görülürken, derin boyun fleksörleri, omuz eksternal rotator, romboid, trapezius (orta/alt liflerinde) kaslarında da güçsüzlük görülür. Bunların sonucunda, serviko-torakal kompleks bozulur. 


\section{PALPASYON}

Üst servikal alanda; atlanto-oksipital eklemin kapsülü, aksisin spinöz proçesi, C1-C2, C2-C3 interlaminar alanlar ve buradaki faset eklemler, atlas ve aksisin transvers proçeslerinin hemen önündeki yumuşak dokular ile oksipital ve suboksipital yumuşak dokular palpasyon ile değerlendirilir. Orta servikal (C3-C5) ve alt servikal (C5-T1) alanlarda; interlaminar alanlar ve faset eklemler, spinöz proçesler, transvers proçesler ile hemen önündeki yumuşak dokular palpe edilerek, hassasiyet, kitle ve instabilite varlığı araştırılır. Klinisyen, infrahiyoid, suprahiyoid, sternokleidomastoid, skalen, pektoralis major, levator skapula, servikal erektör spina ve trapezius kaslarını; servikal omurga disfonksiyonlarında görülebilecek gerginlik ve tetik noktaları palpe ederek değerlendirmelidir. Ayrıca, boyun ön bölümünün palpasyonunda tiroid bezi de incelenmeli, lenfadenopati, tiroglossal kist, tümöral oluşum, karotodini gibi durumların varlığı araştırılmalıdır.

Büyük-orta damar vaskülitleri ve bazı servikal ve üst torakal vertebra kaynaklı patolojiler açısından da periferik arteriyel nabızlar palpe edilmelidir. Ayrıca, servikotorakal sempatik zincirin irritasyonu sonucu, ciltte soğukluk, solukluk, ödem ve terleme artışı görülebileceği akılda tutulmalıdır.

\section{EKLEM HAREKET AÇIKLIĞı (EHA) MUAYENESi}

EHA muayenesi, eklem hareketleri sırasında herhangi bir ses ya da klik alınması, eklem hareketi boyunca gelişebilecek ağrının şekli ve davranışı, eklem hareket açıklığının sonunda direnç varlığı ve eklem hareketi ile gelişebilecek kas spazmı değerlendirmelerini içerir.

Oksiput-C1-C2 kompleksinin primer hareketi, baş onaylama hareketi olan $10^{\circ}$ fleksiyon ve $25^{\circ}$ ekstansiyondur. Bu kompleksin aksiyel rotasyonundan C1-C2 kompartmanı sorumlu iken, oksiput-C1'de minimal lateral fleksiyon hareketi gerçekleşir. Boyun rotasyonunun $\% 50$ 'si C1-C2 arasındadır ve bu segment $45^{\circ}$ rotasyona izin verir. Lateral fleksiyon, tipik olarak C2-C3 segmentinde gerçekleşir. C2-C3 segmentinin altındaki seviyelerde ise lateral fleksiyon hareketi izole olmayıp aynı yöne olan rotasyon ile birliktedir. Servikal bölgede en aktif ve en hareketli kısım C4-C6 arasıdır. Fleksiyon, ekstansiyon ve lateral fleksiyon hareketlerinin çoğunluğu orta servikal segmentte oluşur. Ayrıca, servikal omurganın ekstansiyonunda, açılanmanın en fazla olduğu yer ise C4-C5 segmentidir. ${ }^{[16,17]}$

\section{Aktif Hareket Açıklığının Değerlendirilmesi}

Değerlendirmede artmış hareket paternleri instabiliteyi düşünürür. Segmental kısıtlılıklar saptanması ise hipomobilitenin olduğu seviyeyi belirlememizi sağlar.

\section{Fleksiyon}

Servikal bölgede aktif hareket açıklığı $60^{\circ}$ 'dir. Hareket, üst servikal omurgadan başlayıp torakal 3 . vertebra seviyesine kadar devam eder. Servikal lordozda düzleşme veya tersine dönme olabilir. EHA ölçümü, inklinometre baş üstü midsagittal yerleştirilerek yapılabilir. Hareket sırasında hastanın semptomlarının belirginleşip belirginleşmediğine bakılır. Faset ekleme bağlı segmental kısıtıılık olması halinde, baş ipsilateral tarafa deviye olur.

\section{Ekstansiyon}

Servikal bölgede aktif hareket açıklığı $75^{\circ}$ 'dir. Inklinometre baş üstü midsagittal yerleştirilerek ölçüm yapılır. Faset ekleme bağlı segmental kısıtlılık, hareket sırasında başın kontralateral tarafa deviye olmasına neden olabilir. Hareket sırasında ağrının belirginleşmesi, faset eklem irritasyonuna veya sinir kökü kompresyonuna işaret edebilir.

\section{Lateral fleksiyon}

Aktif hareket açıklığı $45^{\circ}$ 'dir. İnklinometre baş üstü frontal planda yerleştirilerek ölçülür. Hastadan kulağını ve başının yan tarafını omuzuna yaklaştırması istenir. Hareket sırasında ağrının belirginleşmesi, faset eklem irritasyonuna, trapez kasındaki miyofasyal ağrıya veya sinir kökü kompresyonuna bağlı olabilir.

\section{Rotasyon}

Servikal bölgede aktif hareket açıklığı $85^{\circ}$ 'dir. Hastadan başını her iki yana döndürmesi istenir. Eklem hareketi sonunda, çenesinin omuz ile aynı hizada olması beklenir.

\section{Omuz kuşağını destekleyerek yapılan lateral fleksiyon}

Hasta oturur pozisyonda dirsekler $90^{\circ}$ bükülür ve klinisyen dirsekten destekle omuzları yukarı kaldırır. Hastaya başını her iki yöne eğmesi söylenir. Desteksiz yapılan hareketlerle karşılaştırılır. Eğer destekli harekette daha fazla eklem hareket açıklığı saptanırsa, kısıtlılığın ön planda yumuşak doku kaynaklı olduğu düşünülür (örneğin miyofasyal gerginlik). Boyunu her iki yana eğmede benzer kısıtlılık saptanması, patolojinin faset eklem kaynaklı olduğu lehinedir.

\section{Üst torakal rotasyonun değerlendirilmesi}

Hasta rahat pozisyonda ayakta durur veya otururken, klinisyen referans baş parmağını C7 spinöz proçese, diğerini ise $\mathrm{T} 4$ spinöz proçese yerleştirir. Hastadan başını ve boynunu döndürerek sağ/sol omuzuna bakması istenir, klinisyen C7 spinöz proçesteki referans parmağının hareket başlangıcında rotasyon yönünde, hareket sonunda ise rotasyon yönünün tersine ve 
yukarı doğru hareket ettiğini gözlemlemelidir. Referans parmak, sırayla T1, T2'ye de yerleştirilir ve hareketler gözlenir. Bu muayenede, alt servikal-üst torakal kompleksinde hipomobilite varlığı değerlendirilir.

\section{Pasif Fizyolojik Intervertebral Eklem Hareketleri}

Aktif testlerde belirlenen hareket kısıtlılığının seviyesini, miktarını belirlemede ve fark edilemeyen kısıtlılıkları saptamada yardımcıdır.

Hasta supin pozisyonda iken klinisyen, tüm segmentlerde spinöz proçesler ve artiküler sütunları palpe ederek, fleksiyon, ekstansiyon, lateral fleksiyon, rotasyon hareketleri sırasında hipomobilite ve hipermobilite varlığını değerlendirir. ${ }^{[18,19]}$

\section{ÖZEL SERVIKAL TESTLER}

\section{Servikal Foraminal Testler}

\section{Servikal kompresyon testi (Spurling A testi)}

Klinisyen hastanın servikal omurgasını sağ/sol lateral fleksiyona getirir ve baş üzerinden dik açıyla bası uygular, ipsilateral servikal radiküler semptomların gelişmesi, testin pozitif olduğu anlamına gelir.

\section{Spurling B testi}

Servikal ekstansiyon, rotasyon ve lateral fleksiyon hareketleri kombine edilir ve hastada ipsilateral radiküler semptomların gelişmesi, testin pozitif olduğu anlamına gelir.

\section{Servikal distraksiyon testi}

Klinisyen supin pozisyonda yatan hastanın oksiput ve çenesinden kavrar ve aksiyel yönde traksiyon yapar. Mevcut olan radiküler semptomların rahatlaması veya kaybolması, testin pozitif olduğu anlamına gelir.

\section{Omuz abduksiyon rahatlama testi}

Klinisyen hastadan elini başının üstüne getirmek suretiyle abduksiyon yapmasını ister. C5-C6 disk hernisi olan hastalarda ipsilateral yakınmaların rahatlaması, testin pozitif olduğu anlamına gelir.

\section{Instabilite Testleri}

Eklem bütünlük testleri, servikal travma öyküsü olan (örneğin akselerasyon-deselerasyon yaralanması) hastalarda instabiliteden şüphelenildiği takdirde değerlendirilmelidir. ${ }^{[16]}$ Boyun hareketleri ile gelişen denge kaybı, bilateral/kuadrilateral ekstremite parestezileri, nistagmus, yüzde parestezi, dil yarısında hipoestezi yakınmalarından biri veya daha fazlası olan hastalarda değerlendirilmesi gereklidir.

\section{Distraksiyon testi}

Hastanın boynu nötral pozisyonda iken oksipital alandan kavranarak distraksiyon yapılır. Eğer klinik bulgu yoksa test baş ve boyun fleksiyon pozisyonunda iken de tekrarlanır. Testlerde hastanın klinik semptomlarının artması tektoriyel membran kaynaklı üst servikal instabilite varlığını gösterir.

\section{Sagittal stres testi}

Sagittal planda stabiliteyi değerlendiren testlerle, atlantoaksiyel ve atlanto-oksipital instabilite değerlendirilebilir. Sharp-Purser testinde, hasta oturur, baş ve boyun öne fleksiyon pozisyonunda iken, klinisyen C2'nin spinöz proçesini sabitler ve başı nazikçe geriye doğru iter. Bu manevra ile hastanın semptomlarında artış olması, testin pozitif olduğu anlamına gelir ve anterior instabiliteyi işaret eder.

\section{Koronal stres testi; atlantoaksiyel eklem lateral stabilite stres testi}

Hasta supin pozisyonda iken klinisyenin sağ eli oksiput ile atlasın lateral kısmını, diğer eli ise aksisin sol lateral kısmını kavrar. Klinisyen, sol eli ile sağa doğru kuvvet uygular. Aşırı hareket ve hastanın şikayetlerinin belirginleşmesi, lateral instabiliteyi gösterir. ${ }^{[16,20-22]}$

\section{Sinir Sistemi Mobilizasyon Testleri}

Hastanın ağrısına neden olabilecek nöral dokuların dinamik olarak değerlendirildiği testlerdir.

\section{Pasif boyun fleksiyon testi (Lhermitte işareti)}

Pasif öne fleksiyon ile omurgadan aşağıya yayılan ekstremitelerde elektrik çarpma hissi gelişmesi ile test pozitif olarak yorumlanır. Multipl skleroz, tümör, spondiloz gibi lezyonlar sonucu servikal spinal kordun etkilenmesinin işareti olabilir.

\section{Üst ekstremite germe testleri}

Ekstremite germe testleri başlıca, brakiyal pleksusu değerlendiren nörodinamik testlerdir. Servikal omurganın karşı tarafa lateral fleksiyonuna ve retraksiyonuna, çift bacak kaldırma manevraları eklenerek testlerin sensitizasyonu arttırılabilir.

Median sinirin dominant olarak değerlendirildiği testte, omuz depresyon, abduksiyon ve dış rotasyon, dirsek ekstansiyon, önkol supinasyon, el bileği ve parmaklar ekstansiyon pozisyonuna getirilir.

Radyal sinirin dominant olarak değerlendirildiği testte, omuz depresyon ve iç rotasyon, dirsek ekstansiyon, önkol pronasyon, el bileği ve parmaklar fleksiyon pozisyonuna getirilir. 
Ulnar sinirin dominant olarak değerlendirildiği testte ise, omuz abduksiyon ve dış rotasyon, dirsek fleksiyon, önkol pronasyon, el bileği ve parmak fleksiyon pozisyonuna getirilir. ${ }^{[19,20]}$

\section{Slump testi}

Bu test, santral spinal kanal ve dural yapıların esnekliğini değerlendirmede yardımcıdır. Hasta, diz arkası muayene masasının kenarına değecek şekilde oturur. Klinisyen, sağ eliyle hastanın ayağını tutarken sol el ile üst torakal, servikal vertebraları ve başı kavrar. Öncelikle lomber, torakal ve servikal vertebra fleksiyona getirilir ve sol elle baskı uygulanır; sonrasında hastadan dizini ekstansiyona getirmesi istenir; bu aşamada ekstansiyon derecesi ve ağrı yanıtı not edilir. Son aşamada, ayak bileği dorsifleksiyona getirilir ve ağrı yanıtı not edilir. Hasta bir süre bu pozisyonda kaldıktan sonra nötral pozisyona getirilir ve klinik değişkenlik olup olmadığı sorgulanır. Test sırasında alt ekstremite semptomlarının belirginleşmesi, diz ekstansiyonundaki kısıtlılık ve bu kısıtlıığın servikal vertebranın nötrale getirilmesiyle azalması, testin pozitif olduğu anlamına gelmektedir. Servikal omurga fleksiyona getirildikten sonra gelişen boyun ağrısının yumuşak doku, dural yapı veya omuriliğin immobilizasyonu kaynaklı olup olmadığını değerlendirmek için, diz fleksiyondan ekstansiyona getirilir ve hastanın semptomları gözlenir. ${ }^{[16,19,20]}$

\section{Diğer Testler}

\section{Torasik çıkış sendromu muayene testleri}

Torasik çıkış sendromu, üst ekstremiteye giden nörovasküler yapıların skalen üçgen, birinci kosta ile klavikula arası veya subkorakoid alanda sıkışması ile gelişen nörovasküler bir sendromdur. Test sırasında nabızların zayıflaması veya alınmaması 'arteriyel'; uyuşma, karıncalanma, his kaybı gibi semptomların belirginleşmesi 'nörojenik' torasik çıkış sendromunu düşündürür.

\section{Adson manevrası}

Klinisyen, bir eliyle muayene edeceği kolu desteklerken diğer koluyla radyal nabızı palpe eder. Hastadan derin bir inspirasyonla nefesini tutması ve sonrasında başını ekstansiyona getirip muayene edilen ekstremite yönünde döndürmesi istenir.

\section{Hiperabduksiyon testi}

Hastanın dirseği $20-30^{\circ}$ fleksiyona getirildikten sonra pasif abduksiyon yapılır. Klinisyen bir eliyle muayene edeceği kolu desteklerken, diğer koluyla radyal nabzı palpe eder.

\section{Kosta-klaviküler test (abartılı asker duruşu)}

Klinisyen hastanın omuzunu geriye doğru çeker ve aşağıya bastırır. Böylece, klavikula ile 1. kosta birbirine yaklaşmış olur. Hasta bir süre bu pozisyonda bekletilir.

\section{Roos testi}

Hasta oturur veya ayakta pozisyonda iken omuz $90^{\circ}$ abduksiyon ve tam eksternal rotasyona, dirsek de $90^{\circ}$ fleksiyona getirilir. Hastadan $3 \mathrm{dk}$ boyunca parmaklarını açıp kapaması istenir. ${ }^{[18,20]}$ Hareketin tamamlanamadığı tarafta, üst ekstremitede arteriyel yetmezlik oluşturan torasik çıkış sendromu düşünülür.

\section{Baş dönmesi testi}

Baş dönmesi, vertebrobaziller sistem ve vestibüler yapılardan kaynaklanabileceği gibi, propriyoseptif sinir sonlanmalarından zengin üst servikal vertebralardan da kaynaklanabilir. Servikal manipülasyonun kontrendike olması ve olası morbidite potansiyelinden dolayı baş dönmesi yakınması olan hastada, vertebrobaziller yetmezlik değerlendirmesi yapılmalıdır.

Vertebrobaziller yetmezliği değerlendirirken; klinisyen tüm yönleri içeren servikal hareketleri en az $10 \mathrm{sn}$ süre ile pozisyonlar. Semptomların provoke olup olmadığını ve hastada nistagmus gelişip gelişmediğini, geliştiyse nistagmusun yorulup yorulmadığını izler. Ĕger baş dönmesi rotasyon hareketiyle gelişmişse, etiyolojiyi aydınlatmak için rotasyon hareketi ayakta durur pozisyonda da değerlendirilmelidir. Klinisyen hastanın başını sabitlerken, her iki yönde gövde rotasyonlarını yapmasını ister; eğer semptom gelişirse, bu kez hareket uzamış şekilde yapılır. Eğer bu ek testlerde hastanın yakınması belirginleşirse, vestibüler bozukluklar dışlanmış olur. Ayrıca, yapılacak kraniyal sinir muayenesi, vertebral arter hastalıklarını işaret edebilecek ek bulgular saptanmasına yardımcı olabilir. ${ }^{[23]}$

\section{NÖROLOJIK MUAYENE}

\section{Kas ve Kas Gücü Değerlendirmesi}

Klinisyen, servikal kasların uzunluğunu, gerginliğini, gücünü ve ayrıca servikal segmentlerin miyotomlarını değerlendirmelidir (Tablo 1). Günlük uygulamada basitliği ve uygulama kolaylı̆̆ı nedeniyle, sıklıkla yerçekimi ve dirence karşı eklemin hareketini değerlendirme esasına dayanan "manuel kas testi" uygulanır. Buna göre;

0 - Kasta izlenebilir veya palpe edilebilir herhangi bir kasılma yok.

1 - İzlenebilen veya palpe edilebilen kasılma var, ancak bu kasılma herhangi bir eklem hareketi ortaya çıkarmıyor. 
2 - Yerçekimi etkisi ortadan kaldıııldığında kas eklem hareketini tamamlayabiliyor.

3 - Yerçekimine karşı kas eklem hareketini tamamlayabiliyor ama hiç direnç alamıyor.

4 - Uygulanan orta derecede dirence karşı kas eklem hareketini tamamlayabiliyor.

5 - Tam dirence karşı kas eklem hareketini tamamlayabiliyor, demektir.

\section{Duyu Muayenesi}

Her spinal kökün vücutta belirli bir duyu alanı (dermatom) vardır. Dermatomlar, gövdede birbirine paralel horizontal bantlar halindedir; kol ve bacakta ise ekstremitenin uzun aksı boyunca uzanır. Tek bir kökün patolojisinde belirgin bir duyu kaybı görülmez. Bunun nedeni, her dermatomun innervasyonuna bir üst ve alt kökün de katkıda bulunmasıdır.

Hastanın baş, boyun ve üst ekstremitedeki dermatomal alanların ve kraniyal veya periferik sinirler ile uyumlu alanların, hafif dokunma, vibrasyon, ağrı ve ısı testleri ile değerlendirilmesi gerekmektedir. Değerlendirmede saptanacak hipoestezi/hiperestezi, hipoaljezi/hiperaljezi ve allodini alanları not edilmelidir. ${ }^{[24]}$

Tablo 1. Miyotomlar ve değerlendirilen hareketler

\begin{tabular}{ll}
\hline Miyotom & Değerlendirilen hareket \\
\hline C1-C2 & Boyun fleksiyonu \\
C3 & Boyun lateral fleksiyonu \\
C4 & Omuz elevasyonu \\
C5 & Omuz abduksiyonu \\
C6 & Dirsek fleksiyonu, el bileği ekstansiyonu \\
C7 & Dirsek ekstansiyonu \\
C8 & Başparmak ekstansiyonu ve el bileği ulnar \\
& deviyasyonu \\
T1 & Parmak abduksiyonu
\end{tabular}

\section{Kas Germe Refleksleri (KGR)}

KGR muayene notlarına şu şekilde kaydedilebilir: 0: Kayıp veya alınmıyor, \pm : Azalmış, +: Normal, ++: Canlı, +++: Artmış, ++++: Polikinetik. Tablo 2'de, kas germe reflekslerinin ilgili periferik sinirleri ve kök seviyeleri görülmektedir.

KGR'de azalma saptadığımız hastalarda lezyon periferik sinirde ise, refleks kaybına ek olarak ilgili sinirin innerve ettiği kaslarda güçsüzlük ve duyu alanında hipoestezi görülebilir. Arka kökler ve arka kordonun lezyonlarında da refleks kaybı olabilir. KGR'lerin yaygın bir şekilde azalıp kaybolması ise sıklıkla polinöropatilerde görülür.

Hastada artmış ve azalmış KGR'nin birlikte bulunması durumunda ise; artmış reflekslerin üstünde kalan bölgede reflekslerin azalıp kaybolması, lezyon seviyesini gösteren bir bulgu olabilir. Bacaklarında kuvvetsizlik ve artmış tendon refleksleri bulunan, yani piramidal kökenli paraparezi olan bir hastada kollarda refleksler alınmıyorsa, bu tabloda servikal spinal kord lezyonu düşünülmelidir. Bazen birbirine çok yakın iki medulla segmentinden işleyen iki tendon refleksinden üsttekinin azalması, alttakinin ise artması, lezyonun bu iki segment arasında olduğunu gösterir. Örneğin; biseps refleksi başlıca $\mathrm{C} 5$, triseps refleksi de başlıca C6, C7 medulla segmentindendir. Biseps refleksinin kaybına yol açan C5 omurilik segmentindeki bir lezyonda, daha altta kalan triseps refleksinin arttığı görülebilir. Hatta, biseps tendonuna vurulduğu zaman cevap olarak artmış triseps refleksinin alındığı tespit edilebilir. Buna, biseps refleksinin inversiyonu adı verilir. C5, medulla spinalis segmentindeki bir lezyonu gösterir. ${ }^{[24]}$

\section{Patolojik Refleksler}

Patolojik refleksler, birinci motor nöron hastalıklarının delili olarak değerlendirilir.

Tablo 2. Kas germe reflekslerinin ilgili periferik sinirleri ve kök seviyeleri

\begin{tabular}{lll}
\hline Kas & Periferik sinir & Kök seviyesi \\
\hline Biseps & Muskülokutanöz sinir & C5, C6 \\
Brakiyoradyalis & Radyal sinir & C5, C6 \\
Pronator teres & Median sinir & C6, C7 \\
Triseps & Radyal sinir & C7,C8 \\
Patella & Femoral sinir & L2-L4 \\
Mediyal Hamstring & Siyatik sinir tibial kısım & L5-S1 \\
Aşil & Tibial sinir & S1-S2
\end{tabular}




\section{Hoffman bulgusu}

El orta parmak tırnağının fiskelenmesi ile başparmak ve işaret parmağında fleksiyon hareketi gelişmesi, Hoffman refleksinin varlığını gösterir.

\section{Ters (inverted) radyal refleks}

Hastanın önkolu pron pozisyonda iken brakiyoradyalis tendonu üzerine vurulduğunda hipoaktif brakiyoradyal refleks, hiperaktif parmak fleksiyonu gelişmesi ise patolojik refleksin varlığını gösterir.

\section{Babinski bulgusu}

Hasta supin pozisyonda yatırılır. Klinisyen, elindeki sert ve sivri cisim ile hastanın ayak tabanı lateralinden distale doğru ilerler ve mediyale ilerleyerek hareketini tamamlar. Birinci metatarsofalangeal eklemde ekstansiyon, diğer parmaklarda ise yelpaze gibi açılma olması, Babinski bulgusunun varlığı olarak yorumlanır.

\section{Klonus bulgusu}

Hastanın ayak veya el bileğine dorsifleksiyon yönünde hızlı bir germe yapılır ve 2-3 sn hareket sonunda tutulur. Plantar fleksiyon yönünde üçten fazla hareket açığa çıkması klonus varlığını gösterir. ${ }^{[24]}$

\section{SIK GÖRÜLEN BAZI BOYUN SORUNLARINDA FiZiK MUAYENE BULGULARI}

Servikal spondilozda, boyun hareketlerinde lateral fleksiyon ve ekstansiyon daha belirgin etkilenir. Etkilenmiş segmentin spinöz proçes ve faset eklem palpasyonunda hassasiyet saptanabilir.

Servikal radikülopatide, inspeksiyonda postüral değişiklikler, kas atrofileri gözlenebilir. Supraskapularinfraskapular fossada ve deltoid kasında atrofi C5-C6; triseps atrofisi C7; tenar atrofi C8; el intrensek kaslarında atrofi T1 köklerinin etkilendiğini düşündürür. Manuel kas testi bulguları, duyu defisitleri ve refleks değerlendirmesinden daha değerlidir. Bununla birlikte, ağrıdan kaçınma nedeniyle saptanabilen kas güçsüzlügünün, tekrarlayan kas testleri ile ayırt edilmesi gerekir. Dikkat edilmesi gereken, ciddi kas gücü kayıplarında; multipl radikülopati, motor nöron hastalığı, pleksopati, fokal periferik nöropati düşünülmelidir. Spinal kord tutulumunu ayırt etmek için, hafif dokunma, ağrı, vibrasyon duyu testleri, Babinski ve Hoffman patolojik refleksleri değerlendirilmelidir.

Servikal miyelopatide, kas güçsüzlüğü daha çok alt ekstremitelerde belirgindir. Üst ekstremitelerde intrensek el kaslarında atrofi ve güçsüzlük, ön boynuz hücrelerinin etkilendiğini; ağrı ve ısı kaybı, spinotalamik traktusun etkilendiğini; propriyosepsiyon ve vibrasyon kaybı ise dorsal kolonun etkilendiğini gösterir. Üst motor nöron tutulumunu gösteren Babinski ve Hoffman bulguları pozitif olabilir. Klinik yakınma ve bulgular asimetrik veya simetrik olabilir, izole üst ekstremite tutulumu ise nadirdir. Üst ekstremitede asimetrik refleksler veya miyotomal dağılımda kas güçsüzlüğü, eşlik eden radikülopatiyi düşündürmelidir. ${ }^{[25]}$

Kronik boyun ağrısı, majör medikal, sosyal ve ekonomik bir problemdir. ${ }^{[3-6]}$ Doğru tanının erken dönemde konulması klinik iyileşmeyi kolaylaştırır ve sosyoekonomik kayıpların önüne geçer. Ayrıntılı ve dikkatli bir fizik muayene ile, optimal tetkik materyallerine ve tedavi metodlarına yönelim kolaylaşacaktır. İyi bir fizik muayene, genel sağlığın iyileştirilmesinde, zaman ve iş gücü kaybının da önüne geçilmesinde kilit rol oynamaktadır.

\section{KAYNAKLAR}

1. Cohen SP. Epidemiology, diagnosis, and treatment of neck pain. Mayo Clin Proc 2015;90(2):284-99. Crossref

2. Hoy DG, Protani M, De R, Buchbinder R. The epidemiology of neck pain. Best Pract Res Clin Rheumatol 2010;24(6):78392. Crossref

3. Coşkun ME. Boyun Ağrısı ve Tedavisi. Türkiye Klinikleri J Surg Med Sci 2006;2(51):43-7.

4. Taştekin N, Birtane M. Boyun Ağrılarında Tedavi Uygulamaları. Türkiye Klinikleri Journal of Physical Medicine Rehabilitation Special Topics 2009;2:67-74.

5. Yıldız M, Tuna H, Kokino S. Kronik Boyun Ağrılı Olgularda Spinal Mobilite, Ağrı ve Özürlülük Ilişkisinin Değerlendirilmesi. Türk Fiz Tıp Rehab Derg 2005;51(4):127-30.

6. Kuru T, Yeldan I, Zengin A, Kostanoğlu A, Tekeoğlu A, Analay Akbaba Y, Tarakçı D. Erişkinlerde ağrı ve farklı ağrı tedavilerinin prevalansı. Ağrı 2011;23(1):22-7. Crossref

7. Dwyer A, Aprill C, Bogduk N. Cervical zygapophysial joint pain patterns. 1: A study in normal volunteers. Spine (Phila Pa 1976) 1990;15(6):453-7.

8. Carette S, Fehlings MG. Clinical practice. Cervical radiculopathy. N Engl J Med 2005;353(4):392-9. Crossref

9. Baron EM, Young WF. Cervical spondylotic myelopathy: a brief review of its pathophysiology, clinical course, and diagnosis. Neurosurgery 2007;60(1 Supp 1 1):S35-41.

10. Klineberg E. Cervical spondylotic myelopathy: a review of the evidence. Orthop Clin North Am 2010;41(2):193-202. Crossref

11. Oliver J, Middleditch A. Functional Anatomy of the Spine. Oxford: Butterworth-Heinemann Ltd, Reed International Books; 1991. p.1-58.

12. Lipetz Jason S, Lipetz David I. Disorders of the Cervical Spine. In: De Lisa J, editor. De Lisa's Physical Medicine \& Rehabilitation, Principles and Practice, 5th edition. Philadelphia: Lippincott Williams \& Wilkins; 2010. p.811-6.

13. Kendall FP, McCreary EK, Provance PG, Rodgers MM, Romani WA. Muscle Testing and Function With Posture and Pain, 5th ed. Baltimore: Williams \& Wilkins; 2005. p:86-95.

14. Janda V. Muscles and Motor Control in Cervicogenic Disorders. Assessment and Management. In: Grant R, editor. Physical Therapy of the Cervical and Thoracic Spine. New York: Churchill Livingstone; 1994. p.195-215. 
15. Watson D. Cervical headache: an investigation of natural head posture and upper cervical flexor muscle performance. In: Boyling JD, Jull GA, editors. Grieve's Modern Manual Therapy, 2nd ed. New York: Churchill Livingstone; 2004. p.349.

16. Olson K. Spinal Examination and Diagnosis in Ortopaedic Manual Physical Therapy. In: Olson K, editor. Manual Physical Therapy of the Spine 2nd ed. St. Louis: Elsevier Science; 2016. p.30-68.

17. Allen A, Fraser M, Bogduk N. Examination of the Cervical and Thoracic Spine. In: Grant R, editor. Physical Therapy of the Cervical and Thoracic Spine, 3rd ed. Churchill Livingstone; 2002. p.105-58.

18. Freiberg Joseph $\mathrm{H}$, Moley Peter J. Examination of the Cervical Spine. In: De Lisa J. De Lisa's Physical Medicine \& Rehabilitation Principles and Practice 5th ed. Philadelphia: Lippincott Williams \& Wilkins; 2010. p.55-7.

19. McKenzie R, May S. The Cervical \& Thoracic Spine: Mechanical Diagnosis \& Therapy, 2nd ed. Raumati Beach, New Zealand: Spinal Publications Ltd.; 2006. p.71-98.
20. Winkel D, Aufdemkampe G, Matthijs O, Meijer OG. Diagnosis and Treatment of the Spine. Winkel D, editor. Gaithersburg, Maryland: Aspen Publications; 1996. p.937-47.

21. Van der El A. Examination of the Cervical Spine. In: Van der El A, editor. Orthopaedic Manual Therapy Diagnosis: Spine and Temporomandibular Joints. Sudbury MA: Jones and Barlett Publishers; 2010. p.440-98.

22. Pettman E. Stress tests of the craniovertebral joints. In: Boyling D, Palastanga N, editor. Grieve's Modern Manual Therapy: The Vertebral Column, 2nd ed. Edinburgh, UK: Livingston Churchill; 1994. p.529.

23. Slipman Curtis W, De Palma J. Common Neck Problems. In: Braddom R, editor. Physical Medicine \& Rehabilitation, 4th ed. Philadelphia: Elsevier Saunders; 2010. p.780-810.

24. Bahar Z, Aktin E. Nörolojik muayene. In: Bahar Z, Aktin E, editörler. Sinir Sistemi Semiyolojisi. İstanbul: ITF; 2009. p.105-19.

25. Magarey ME, Rebbeck T, Coughlan B, Grimmer K, Rivett DA, Refshauge K. Pre-manipulative testing of the cervical spine review, revision and new clinical guidelines. Man Ther 2004;9(2):95-108. 